\title{
Review
}

Pak. j. sci. ind. res. Ser. B: biol. sci. 201457 (3) 165-174

\section{Some Aspects of Developmental Trends in Chemical Modification and Transformation of Starch: Products Preparation and Potential Applications}

\author{
Bode Daramola \\ Department of Food Technology, Federal Polytechnic, Ado-Ekiti, Ekiti State, Nigeria
}

(received January 21, 2014; revised June 19, 2014; accepted August 28, 2014)

\begin{abstract}
Starch, a non-depleting bioresource has a myriad of applications both in the food and nonfood industries. These applications are made possible by starch modification technology. Chemical method of starch modification, the most versatile tool in accomplishing the preparation of copious starch speciality products or by-product which could serve as feed stock or precursor for the preparation of allied products is reviewed. The applicabilities of the speciality starch produced by chemical modification presented in many research papers are surveyed and pooled together and reviewed in this paper. This study suggests the myriads of opportunity that exist using chemical method of starch modification and transformation that have immerse applications in both, food and non-food industries. A projection on the future of chemical method of starch modification is highlighted.This review will motivate readership to seek accurate detail knowledge on chemical method of starch modification and transformation for technological and economic advancement.
\end{abstract}

Keywords: chemical modification, starch speciality products, transformation

\section{Introduction}

Starch is the most important reserve carbohydrate and one of the most abundant organic chemicals on earth (Jane et al., 1994). It could be found in the leaves of green plants in the plastids, more importantly, starch is synthesised in any plant and stored abundantly in seeds, grains, roots and tubers of many plants. The principal commercial sources of starch are roots and tubers (cassava, potato and arrow root), cereals (maize, rice and wheat), fruits (banana, plantain and breadfruit) and pith of plants (sago palm). Starch is not region-selective, as a result all countries are endowed with the possibility of abundant supply of starch provided there is vegetation. The abundance of starch spurs scientists to search for food related and non-food applications of starch. Unfortunately, starch in its native form has limited industrial applications whether in food and non-food industries. Interestingly, the properties of native starch can be altered using minor modification such that positive attributes can be greatly improved and/or negative characteristics diminished by slight and relative simple modifications (BeMiller, 1997). The primary reasons for starch modification have been tabulated by BeMiller (1997). Yaacob et al. (2011) reported that from 1969 to 2001, there have been more than 23,000, scientific articles in food science and technology. Therefore, it is E-mail: daramola_bode@yahoo.co.uk vivid that a comprehensive review of chemical aspect of starch modification for food and non-food applications cannot be accomplished within the limited space of this article. However, it is important to make a list of some texts notably, Wurzburg (1986); Mentzer et al. (1984) and Rutenberg (1980) that could furnish pioneer technology details and lead references on starch modification. Beyond the content and period of the cited references, a lot of research progress has been reported in many articles. Therefore, it would be informative and educative to pool some of these articles into one piece in a review.

This study aimed at brief review of developments in chemical method of starch modification and transformation for both food and non-food applications, and some of the manipulations employed to enhance or conferred the product-value-addition. This will motivate readership to seek further knowledge on details of technological accomplishment for preparation of value added products and organic-compliant substitute from starch.

Chemical method of starch modification. Inherent properties of native starch could be changed for industrial compilation and the basic modification types practiced in the US is presented in Table 1. However, of all the methods listed, chemical process offers the highest number of modification opportunities, hence focussed herein. 
Table 1. Modification methods and probable conferred attributes

\begin{tabular}{|c|c|}
\hline Types of modification & Probable attribute conferred \\
\hline \multicolumn{2}{|l|}{$\begin{array}{l}\text { I. Chemical modification } \\
\text { A. Derivatisation }\end{array}$} \\
\hline $\begin{array}{l}\text { 1. Monostarch substitution } \\
\text { (etherification and } \\
\text { esterification, including } \\
\text { polymer grafting) }\end{array}$ & Improved paste clarity \\
\hline $\begin{array}{l}\text { 2. Cross linking } \\
\text { (via distarch } \\
\text { esterification) }\end{array}$ & $\begin{array}{l}\text { Increase paste stability, } \\
\text { lower tendency to retrograde, } \\
\text { increase water solubility, } \\
\text { improved water solubility. }\end{array}$ \\
\hline $\begin{array}{l}\text { B. Acid thinning/hydrolytic } \\
\text { depolymerisation }\end{array}$ & $\begin{array}{l}\text { Increase clarity/increase in } \\
\text { digestibility }\end{array}$ \\
\hline $\begin{array}{l}\text { C. Dextrinisation } \\
\text { (depolymerisation and } \\
\text { trans-glycosylation }\end{array}$ & Increase in digestibility \\
\hline $\begin{array}{l}\text { D. Oxidation (bleaching } \\
\text { and depolymerisation) }\end{array}$ & Increase in clarity \\
\hline $\begin{array}{l}\text { E. Hydrolysis (malto- } \\
\text { dextrins, glucose syrup, } \\
\text { glucose etc. - both acid } \\
\text { and enzyme-catalysed. }\end{array}$ & Increase in digestibility \\
\hline \multicolumn{2}{|l|}{ II Physical modification } \\
\hline A. Pre-gelatinised process & Cold water solubility \\
\hline \multicolumn{2}{|l|}{$\begin{array}{l}\text { B. Preparation of cold-water } \\
\text { swelling starch }\end{array}$} \\
\hline \multicolumn{2}{|l|}{ III Genetic } \\
\hline $\begin{array}{l}\text { A. Waxy starch } \\
\text { B. High-amylose starch }\end{array}$ & Variable quality profile \\
\hline
\end{tabular}

Source: BeMiller (1997).

The characteristics cooks of native starch, irrespective of the source are undesirable for many industrial applications. This is because, they are susceptible to retrogradation, syneresis, unwanted viscosity as a result of their inability to withstand the typical industrial processing conditions such as extreme temperature, $\mathrm{pH}$, high shear rate, and freeze thaw variation encountered during manufacture of food and allied products. Some of the positive attributes conferred by modification of starch in foods are reported in a review by Daramola and Falade (2006). Since this article captions chemical method of starch modification, it is necessary to explain in brevity the chemical aspect of starch modification outlined in Table 1.

Acid thinning. Acid thinning involves hydrolysis of starch by applications of both organic and inorganic acids to break starch molecular chains namely: amylose and amylopectin. Some of the inorganic acids used are hydrochloric acid, sulphuric acid and phosphoric acid (Whistler et al.,1984), and organic acids anhydride used include succinic acid anhydride, acetic acid anhydride, (Wang et al., 1997; Agboola et al., 1991).

Oxidation. This involves the use of reagents such as sodium hypochlorite, potassium permanganate and sodium chlorite. All can be used in both acidic and alkaline medium (Kweon et al., 2001).

Derivatisation. As listed in Table 1, derivatisation can be divided into 2 sub-groups:

(1) Starch monosubstition in nature of etherification and esterification as well as forms of polymer grafting. Any substitution of the hydroxyl moiety on the molecular chains of starch by alkoxide and alkanoate is referred to as etherification and esterification, respectively. Examples of this type of modification is acetylation of starch (Daramola and Adegoke, 2007; Lawal, 2004).

(2) Another example is starch citrates (Agboola et al., 1991) and propyl-etherified starch (Teramoto et al., 2003). In addition, starch ethers could be cationised or anionised, a described procedure has been reported by Kweon et al. (1997). Also, preparation of starch succinates by reactive extrusion has been reported by Wang et al. (1997). Starch can be modified to carry charges positive (cation) or negative (anion) or both. When cation and anion are combined on a single starch it is termed amphoteric starch. Amphoteric starches, could be etherified, esterified, or grafted starches which simultaneously, contain cationic groups and anionic groups. Generally, the cationic groups could be amino, ammonium, sulphonium or phosphonium. Presently, tertiary amino groups or quaternary ammonium groups are the most important industrial positive group (moiety). Anionic groups are usually carboxyl groups, phosphate groups or sulphonate groups (Yang et al., 2007). A cheap reagent such as alum (double salt) has been used to modify starch as reported in an earlier study by Daramola and Aina (2007).

Starch cross-linkage. Starch cross-linkage could be accomplished using bi-functional compounds, which are capable of reacting simultaneously, with two or more hydroxyl groups in starch forming cross-linked starch. Examples of such compounds are phosphorus oxychloride, epichlorohydrin and sodium trimetaphosphate used mostly for food grade cross-linked starches (Radley, 1976). Cross-linkage facilitates intra and intermolecular bonds at random locations in the starch granules for their stabilisation. As a result of the intra and intermolecular 
linkages, paste of cross linked starch are more resistant to shear, and acidic conditions (Majzoobi et al., 2009). All the starch derivatives have amazing technological applications as illustratively summarised in Table 2 .

Fundamental factors affecting starch modification using chemical method. The factors affecting starch modification using chemical method can be divided into three classes:

(1) The primary factors which include processing variables such as temperature, solid solvent ratio, stirring rate, concentration of solvent, time and pressure.

(2). The secondary factors are type or chemical nature of solvent (e.g. acid, alkanol, alkaline, esterification and etherification reagents). Nature of chemical is majorly affected by the chemical or inherent functional groups. Added to these methods of processing are: use of reactive extrusion (Wang et al., 1997), microwave heating (Shogren and Biswas, 2006) and use of ionic liquids among others. Also in this group, the use of catalysts, initiator, promoters and modifiers.

(3) The tertiary factors involves: high technology, involving manipulation of active site in molecular chains and granules of starch and combination of chemical method for modification of starch. For example, it is possible to combine cross-linkage method with ionic method in one of the modification. Another one is chemical modification of starch in solvent free environment (Aburto et al., 2005).

Instrumentation in chemical method of starch modification. The commonest analytical instruments for characterisation of modified starch accomplished using chemical method are viscosity analyses (RVA). RVA profiles, the pasting characteristics such as peak viscosity, set back viscosity, final viscosity, pasting temperature and time of starch. Their technological interpretation signifies the extent of conferred modification (Meadow, 2002; Delcour et al., 2000; Deffenbaugh and Walker, 1990; 1989).

Similarly, the thermal characteristics could be studied using a differential scanning calorimeter (DSC). Some of the evaluated parameters are: onset temperature, peak temperature, completion temperature and gelatinisation enthalpy. With the understanding that the two molecular chains, amylose and amylopectin are folded into granule and the fact that there are no two starch granules that are exactly same in terms of size, shape and configuration. Therefore, starch morphological characteristics are studied using scanning electron microscopy (SEM) (Jane et al., 1994; Jing-ming and Sen-lin, 1990). Besides morphological characteristics, SEM gives insight to location and conformation of hilum that contain the cavity through which chemical moiety passes into the amylose and amylopectin chains. Other importance of SEM on starch granules involves revelation on integrity of starch granule to hydration and dehydration and vapour pressure. It also reveals relationship between starch granules disruption and physicochemical properties of starch.

Structural characteristics of starch could be evaluated using fourier transform-infrared (FTIR). FTIR is important in revealing degree of substitution and the substituent chemical moiety. Other analytical instruments include; x-ray diffraction analytics, and nuclear magnetic resonance. Convectional tests carried out on starch are paste clarity, swelling capacity, solubility, tensile strength, stress, elongation at break, and tear strength. Other assessed parameters are apparent viscosity, freeze thaw stability, gel strength and thermal stability analysis (Chung et al., 2004).

Preparation of starch noodle. Besides the additives application of starch in food preparations, where it could function as binding or adhesion, clouding and dusting agents. Other functions include flowing aid, antistaling and gelling agents. Starch is also used to glaze, mould, shape and thicken during food preparations. Examples of food in which starch performed the itemized functions have been tabulated by Ihekoronye and Ngoddy (1985), as reviewed by Daramola and Falade (2006).

Beyond the uses of speciality starch as additives as previously explained, food can be produced using whole starch. Noodles can be produced from starch. Although, starch is void of gluten, pregelatinised starch is used as binder mixed with ungelatinised starch to facilitate extrusion or sheeting to produce noodles. Basic protocol for the commercial production of bihon-type noodles can be found in literature (Tam et al., 2004).

Food noodles can be prepared from flour or starch, provided the product has noodles qualities that are defined by visual attributes, cooking and eating qualities, transparency and glossiness. In cooked starch noodles, the noodles should remain firm and not sticky on standing after cooking. These characteristics have positive correlation to noodles texture and mouth feel acceptance.

Starch transformation. Precursor of starch sweeteners and other organic chemicals. Sweetener can be produced from starch using varieties of acids (Daramola and Falade, 
Table 2. Starch derivatives and potential applications

\begin{tabular}{|c|c|c|c|}
\hline $\begin{array}{l}\text { Modified } \\
\text { starch/description }\end{array}$ & Modification type & Domain of application & Leading references \\
\hline $\begin{array}{l}\text { Complexes of oppositely } \\
\text { charged ionic starches e.g., } \\
\text { polyelectrolyte complexes }\end{array}$ & Amphoteric & $\begin{array}{l}\text { Medicine: dialysis, } \\
\text { ultrafiltration anti- } \\
\text { thromobogenic agent }\end{array}$ & Willett, 1995 \\
\hline Oxidized starch & $\begin{array}{l}\text { Oxidation } \mathrm{H}_{2} \mathrm{O}_{2} \mathrm{Cu}^{2+} \\
\left(\mathrm{CuSO}_{4}\right) \text { catalyst } \mathrm{Fe}^{2+} \\
\left(\mathrm{FeS} \mathrm{O}_{4}\right)\end{array}$ & $\begin{array}{l}\text { Paper industry: surface } \\
\text { sizing coating and } \\
\text { binding }\end{array}$ & Parovuori et al., 1995 \\
\hline $\begin{array}{l}\text { Carboxymethylation } \\
\text { of starch propyl- } \\
\text { etherification of starch }\end{array}$ & $\begin{array}{l}\text { Etherification alkaline } \\
\text { Sodium-mono } \\
\text { chlorocetate 1-bromo } \\
\text { propane }\end{array}$ & $\begin{array}{l}\text { Biodegradable } \\
\text { polymer for coating } \\
\text { for food and } \\
\text { pharmaceutical } \\
\text { products }\end{array}$ & $\begin{array}{l}\text { Yaacob et al., 2011; } \\
\text { Teramoto et al., } 2003\end{array}$ \\
\hline Amphotenic starches & $\begin{array}{l}\text { Amphoteric starches: } \\
\text { Etherification, } \\
\text { Esterification, } \\
\text { Grafting }\end{array}$ & $\begin{array}{l}\text { Paper making } \\
\text { additives, for } \\
\text { retention, and } \\
\text { strength properties }\end{array}$ & Yang et al., 2007 \\
\hline Cross-linked starch & $\begin{array}{l}\text { Cross-linkage } \\
\text { phosphoryl chloride }\end{array}$ & $\begin{array}{l}\text { Food additives: } \\
\text { thickners, colloidal } \\
\text { stabilizer, water } \\
\text { retention, agents for } \\
\text { food and Non-food } \\
\text { waste } \mathrm{H}_{2} \mathrm{O} \text { treatment }\end{array}$ & $\begin{array}{l}\text { Majzoobi et al., 2009; } \\
\text { Wang et al., } 2005\end{array}$ \\
\hline $\begin{array}{l}\text { Cross-linked, } \\
\text { cationised anionised } \\
\text { amphoteric }\end{array}$ & $\begin{array}{l}\text { Esterification, } \\
\text { Etherification }\end{array}$ & $\begin{array}{l}\text { To bind heavy metals } \\
\text { from waste water } \\
\text { waste treatment }\end{array}$ & $\begin{array}{l}\text { Carmona-Garcia, et al., } \\
2009\end{array}$ \\
\hline $\begin{array}{l}\text { Cross-linked } \\
\text { hydrophilic polymers } \\
\text { super absorbent }\end{array}$ & $\begin{array}{l}\text { Graft co-polymeric } \\
\text { cation }\end{array}$ & $\begin{array}{l}\text { Surgical pad } \\
\text { pharmaceutical, } \\
\text { domestic, sanitary } \\
\text { use, soil condition }\end{array}$ & $\begin{array}{l}\text { Xiao et al., 2010; } \\
\text { Liu et al., } 1996\end{array}$ \\
\hline $\begin{array}{l}\text { Complexation of } \\
\text { modified starch with } \\
\text { pigment }\end{array}$ & $\begin{array}{l}\text { Complexation with } \\
\text { pigment }\end{array}$ & $\begin{array}{l}\text { Improvement of } \\
\text { optical and pant ability } \\
\text { performance of water }\end{array}$ & Kuuti et al., 2010 \\
\hline $\begin{array}{l}\text { Etherification and } \\
\text { cross-linkage }\end{array}$ & $\begin{array}{l}\text { Cationization graft- } \\
\text { copolymerization }\end{array}$ & $\begin{array}{l}\text { Water treatment as } \\
\text { flocculant in } \\
\text { place of alum }\end{array}$ & $\begin{array}{l}\text { Yang et al.,2007; } \\
\text { Sharma et al., } 2006\end{array}$ \\
\hline Cross-linkage of starch & $\begin{array}{l}\text { High performance } \\
\text { elastomer } \\
\text { (Tyre-making) }\end{array}$ & & $\begin{array}{l}\text { Song et al., 2010; } \\
\text { Qing et al., } 2006\end{array}$ \\
\hline $\begin{array}{l}\text { Aerogels } \\
\text { based microcellular } \\
\text { foams }\end{array}$ & $\begin{array}{l}\text { Microcellular starch- } \\
\text { for production of } \\
\text { synthetic foam }\end{array}$ & $\begin{array}{l}\text { Alterative material } \\
\mathrm{Xu} \text { et al., } 2005\end{array}$ & $\begin{array}{l}\text { Xu et al., 2005; } \\
\text { Glenn and Irving, } 1995\end{array}$ \\
\hline
\end{tabular}


2006). Some of the obtained products are glucose, maltose, dextrin and maltose. These sweeteners are superior on the basis of dearth of physiological abnormalities associated with sweetener of synthetic origin.

Starch sweeteners have been produced from starch using acids such as hydrochloric acid, sulphuric acid and phosphoric acid. Each of the acids has its advantages and limitation. For instance, hydrochloric acid is an inorganic acid and it hydrolyse starch and the hydrolysis is complete in comparison to hydrolysis carried out by using phosphoric acid. Nevertheless, sweeteners obtained from hydrochloric acid hydrolysed starch require treatment and other purification processes. However, phosphoric acid hydrolysed starch can be used directly for biological production of ethanol without purification. The application or use of phosphoric acid rather than hydrochloric acid presents some advantages. Phosphoric acid is non-volatile and safer to handle in comparison to hydrochloric acid. Since, phosphoric acid is less severe in comparison to hydrochloric acid, it could be speculated that the application of phosphoric acid should be accompanied by lesser by-products. The hydrolysed starch or sweetener can be diluted on addition to foods or beverages, the phosphoric acid concentration falls to values as low as $0.01-0.05 \%$ resulting to a pleasant taste of acidity at $\mathrm{pH}$ values of about 3.0. More importantly, if the hydrolysate is to be used in fermentation, there is no need to eliminate the phosphoric acid. Interestingly, neutralisation with ammonia leads to ammonium phosphate, an important supplement for fermentation growth (Fontana et al., 2008). The products from starch hydrolysis, called hydrolysates are made of molecules of different length, consequently, in addition to neutra-lisation and purification, the hydrolysates are fractionated using chromatographic techniques. Three distinct products namely, glucose, maltose and oligosaccharides fractions are recovered. This is one of the starch processing methods patented (Masuda et al., 1995). Besides being used as sweetener, the hydrolysate is also an ingredient for formulation of tablet coats (Czarnecki and Belniak, 2009).

Aside, from application of acids to hydrolyse starch, alkaline such as sodium hydroxide, potassium hydroxide can be used to depolymerise starch at high temperature approximately $240{ }^{\circ} \mathrm{C}$ for a period not less than $60 \mathrm{~min}$ to yield organic compounds such as glycol and oxalic acids (Verendel et al., 2011). It is important to state that some of the end-products of starch hydrolysis notably glucose and maltose could be further modified and transformed to organic chemicals such as ethanol, hydroxyl methyl furfural (Zhang et al., 2012), and fructose (Roman-Leshkov et al., 2010), lactic acid and other feedstock chemicals.

Some miscellaneous modified starch products: Modified starch has applications in many different industries (Table 3) that range from food, drug and medicine to non food industries such as mining, building and electronic industries. Some of these are illustrated hereunder: other than cooking, native starch can be treated or modified to become granular, cold water soluble. The preparation of this kind of speciality of starch using alcoholic-alkaline treatment had been reported by Chen and Jane (1994). Another procedure that used liquid ammonia and ethanol was also described by Jackowski et al. (2002). Other novel product include functional modification of starch by esterification of the hydroxyl group by introduction of a chromophoric moiety leading to development of a thermostable and photo-responsive system on starch. A procedure of this kind had been reported by Chandran et al. (2012). A starch benzyl ether of high degree of substitution has a unique property of being not gelatinised when cooked at $100^{\circ} \mathrm{C}$. However, when prepared at super atmosphere in a steam injection cooker at $150^{\circ} \mathrm{C}$, dispersion fluid sol results, which when cast gives resistant films.

Most chemical modification of starch is based on material science properties. Starch could also be modified for exhibition of certain nutritional functionality other than dietary fibre. Starch could be conjugated to non-starchy substances thereby, lending significant changes in starch nutritional functionality. This was demonstrated by the work of Hatton et al. (1995), that changed the functional properties of carboxymethyl potato starch conjugated with whey proteins. The covalently linked carboxymethyl potato starch-whey was characterised by improved thermal stability and reduced retrogradation in comparison to unmodified starch. Also the conjugated starch-whey product possessed retinol binding ability present in $\beta$ - lactoglobulin present in whey and $\alpha$-lactoalbumin present in whey known to participate in lactose synthetase reaction. One of the reasons for turning to starch for synthesis of starch-materials is its biodegrability. This is expressed in the capability of microorganisms to decompose polymeric materials to low molecular compounds, such as carbondioxide and nitrogen, so that carbon returns to the ground/soil or atmosphere. Beyond this, today research is focussing on dissembling the blocks coupled within functionalised starch. This claim has been demonstrated in the research of AuzelyVelty and Rinaudo (2003), for the synthesised starch- 
Table 3. Spectrum of modified starch utilising industries with example of application

\begin{tabular}{|c|c|}
\hline Industry & Application \\
\hline Food processing & $\begin{array}{l}\text { Pie filling, padding, mixes, fruit } \\
\text { juice sources, bulking agent, } \\
\text { molds, fluidifying agent main- } \\
\text { tenance of viscosity in acid foods } \\
\text { e.g., fruit juice, decrease syneresis } \\
\text { in ice-cream or refrigerated } \\
\text { foods. Hard candy gum drops }\end{array}$ \\
\hline Paper/board/corrugating & $\begin{array}{l}\text { Pigment retention on paper } \\
\text { (wet-end addition), as surface } \\
\text { sizing agent coating }\end{array}$ \\
\hline Brewing & as adjunct \\
\hline Textile/warp sizing & $\begin{array}{l}\text { Text finishing agents to add } \\
\text { weight, smoothness and stiffness }\end{array}$ \\
\hline Pharmaceuticals & $\begin{array}{l}\text { Cosmetics: tooth paste, body } \\
\text { cream or lotion } \\
\text { Pharmaceutical tablets; binder, } \\
\text { filler, disintegrant } \\
\text { Body powders }\end{array}$ \\
\hline Building pots & Binder for foundries \\
\hline Agriculture & Soil conditioners \\
\hline Adhesives & $\begin{array}{l}\text { Corrugated boards } \\
\text { paper bag } \\
\text { Guming applications }\end{array}$ \\
\hline Crude oil mining & Oil drilling mud \\
\hline Briquetting & Domestic and industrial heating \\
\hline Packaging & $\begin{array}{l}\text { Plastics } \\
\text { High temperature stable hybrid } \\
\text { nylon e.g., meat roasting nylon; } \\
\text { Edible films } \\
\text { Preparation of surgeon gloves }\end{array}$ \\
\hline
\end{tabular}

betaine derivatives using disopropylcarbodiimide and 4-dimethylaminopyridine as coupling agents in an aprotic polar solvent, which carry cleavable cationic groups derived from naturally occurring glycine-betanine. The improvement in this study, lies in lower toxicity and larger biodegradability in comparison to the traditional cationic surfactant compounds.

Some modification enhancement manipulations. Although BeMiller (1997) in an earlier review predicted that there could not be approval of new reagents for derivation of starch, for safety concerns. However, as knowledge expands, new reagents with special attributes are discovered and other process enhancement manipulation. Two examples shall be discussed in brevity.

Use of ionic liquids. For example, effort on the use of ionic liquids as solvent for reaction-medium for starch has started to receive attention. Ionic liquids are a new technology considered to be green chemistry because of their biodegradability, and low toxicity. Added to this, ionic liquids have a spectrum of compound characteristics through a broad selection of anions and cations combi-nations. Other advantages inherent to ionic liquids are non-flammability and thermal stabilities and enhancement of reaction rates with higher selectivity, an example of such study is an early work of Stevenson et al. (2007) on changes in structure and properties of starch of four botanical sources dispersed in ionic liquid. Besides, acting as solvent, ionic liquids have been reported to exhibit catalytic property. This was demonstrated by acylation of maltodextrin in ionic liquid (Biswas et al., 2009). This process obviates the use of catalyst during acylation of maltodextrin with its economic and technical advantages.

Application of enhanced microwave heating. Starch can be hydrolysed using microwave field. The advantage of this form of heating lies in dissipation of heat inside the medium, which raises the energy of the molecules rapidity. This heating mode is different from convectional heating because all the molecules in the heated system receive same amount and rate of heat readily energized and resulting to higher reaction rates and greater selectivity. The afore-described process could be enhanced by the addition of metallic halides such as sodium chloride, potassium chloride, iron III chloride to the microwave heating solvent or medium. The importance of the inorganic salts could be demonstrated by the amount of (88-109 wt \%) glucose hydrolysed from starch using hydrochloric acid for a period of 240 $\mathrm{s}$ at a temperature of $145^{\circ} \mathrm{C}$, while the control sample without salt (all other conditions were same), yielded less glucose ( $78 \mathrm{wt} \%$ ) not earlier than a period of $600 \mathrm{~s}$ as demonstrated in the study of Kunlan et al. (2001).

Future prospects of chemical method of starch modification. Since chemical modification offers the most versatile opportunities of tailoring starch granules to fit for a particular properties/purpose/application, the future appears bright regarding the relevance of chemical modification of starch for products or preparation of speciality starch for food and non-food applications than is known presently. Another important reason for good prospects for continuous progress or advancement in 
chemicals modification of starch is the peculiarities of starch as a bioresource as outlined in Table 4. Additional projection on the future of chemical method of starch modification and prospective application is as follows: The future of chemical method of starch modification would be addressed from the two broad domain of application namely: (1) food application and (2) non-food application. Regarding food application perspective, there are no indications that new chemicals would be approved for modification of starch to be used in food processing. This is in agreement with the prediction of BeMiller (1997). However, any new chemical to be used for modification of starch for food would undergo strict examination to have passed safety test for approval. Beyond this, chemical modification processes for starch could be enhanced by combination with use of novel solvents such as ionic liquid as medium of reaction and catalytic agent (Biswas et al., 2009). Also chemical modification could be combined with physical process such as irradiation. Regarding chemical modification of starch for application in peripheral food and non-food applications, there exists an open end opportunity. Chemical modification of starch in preparation of edible packaging materials used in fast foods and institutional catering and short-time, and self degradative packaging that could be used as packaging materials in bottling of table water and flocculating agents. Such products could be prepared using starch and long chain fatty acids of different unsaturation and alkylation. Polymeric materials have inexhaustive applications list in bioprocessing. The aim of this section is to articulate the need and the possibility of using starch to replace the other materials produced from non-starchy or petrochemical products. Most especially, that biodegradability is of priority in material science, and polymer technology in present day technology. In separation technology, molecularly imprinted polymers (MIPs) have been applied in adsorptive

Table 4. Starch bioresource peculiarities

Starch sources is non-regional specific

Starch is abundant

Renewable/sustainability

Ecofriendly or non-toxic

Amenable to modification in comparison to cellulose

and chitin much available bioresource

Inexpensive

Biodegradable

Availabilities of many reaction sites

Modification is not high technology

Procedure is less labourious and operational hazard

Non-depleting separation as selective chromatographic materials and in the field of solid phase extraction. MIP is a synthetic porous polymer with selective and specific recognition ability of the binding cavities to target molecules by non-covalent interactions such as hydrogen bonding, electrostatic interactions $\pi-\pi$ and hydrophobic forces as reported by Seechamnanturakit and Suede (2012).

In addition, verse opportunities await application of starch modified to meet application as immobilised enzymes with respect to reversibly soluble-insoluble polymer. Presently, all the polymers used in enzyme immobilisation are synthetic (Dourado et al., 2002) consequently, it would be more friendly to use biodegradable polymer of starch origin. Finally, chemically modified starch would find place in other stimuli-responsive polymers, sometimes referred to as smart or intelligent polymers which are presently dominated by synthetic polymers. Stimuliresponsive polymers have a series of biological applications, which include tissue engineering, drug release systems, biological sensors, temperature and light responsive films or optical sensors, intelligent microfluidic switches and diagnostic devices (Milichovsky, 2010) consequently an important tool in automation of bioprocess.

\section{Conclusion}

The admirable potentials of chemical modification technology to produce speciality starch with both, food and non-food applications are reviewed. This by no means exhaust the modification and transformation of starch for both food and non-food industrial applications. It is anticipated that this review would motivate readership to seek detail and accurate technology knowledge on know-how-accomplishment to develop domestic starch for import substitution for technological and economic benefits.

\section{References}

Aburto, J., Alric, I., Borredon, E. 2005. Organic solvent free transesterification of various starches with lauric acid methyl ester and triacyl glycerides. Starch/Starke, 57: 145-152.

Agboola, S.O., Akingbala, J.O., Oguntimein, G.B.1991. Production of low substituted cassava starch acetate and citrates. Starch/Starke, 43: 13-15.

Auzely-Velty, R., Rinaudo, M. 2003. Synthesis of starch derivatives with labile cationic group. International Journal of Biological Macromolecules 31: 123-129. BeMiller, J.N. 1997. Starch modification: challenges and 
prospects. Starch/Starke, 49: 127-131.

Biswas, A., Shogren, R.L., Willet, J.L. 2009. Ionic liquid as a solvent and catalyst for acylation of maltodextrin. Industrial Crops and Products, 30: 172-175.

Carmonai-Garcia, R., Sanchez-Rivera, M.M., MendezMontealvo, G.., Bello-Perez, L.A., Garza-Montoya, B. 2009. Effect of the cross-linked reagent type on some morphological, physicochemical and functional characteristics of banana starch (Musa paradisiaca). Carbohydrate Polymers, 76: 117-122.

Chandran, A., Kuriakose, S., Mathew, T. 2012. Thermal and photoresponsive studies of starch modified with 2-(5-(4- Dimethylamino-benzylidine-4-oxo-2-thioxothiazolidine)-3-yl) acetic acid. International Journal of Carbohydrate Chemistry, 2012: Article ID 356563, pp. 8, http://dx.doi.org/10.1155/2112/566563.

Chen, J., Jane, J. 1994. Preparation of granular coldwater-soluble starches by alcohol-alkaline treatment. Cereal Chemistry, 71: 618-622.

Chung, H.J., Woo, K.S., Lim, S.T. 2004. Glass transition and enthalpy relaxation of cross-linked corn starches. Carbohydrate Polymers, 55: 9-15.

Czarnecki, W., Belniak, P. 2009. Tablets coated with the novel starch hydrolysate emulsion. Acta Poloniae Pharmaceutica, 66: 429-431.

Daramola, B., Adegoke, G.O. 2007. Production and Partial characterisation of food grade breadfruit acetylated starch. Journal of Food, Agriculture and Environment, 5: 50-54.

Daramola, B., Aina, J.O. 2007. Effects of alum on pasting and some physicochemical properties of cassava (Manihot esculentum) Starch. World Journal of Diary and Food Sciences, 2: 18-22.

Daramola, B., Falade, K.O. 2006. Enhancement of agronomical values: upstream and downstream opportunities for starch and starch adjuncts. African Journal of Biotechnology, 5: 2488-2494.

Deffenbaugh, L.B., Walker, C.E. 1990. Use of the rapid visco-analyzer to measure starch pasting properties, Part II: effect of emulsifiers and sugar-emulsifier interactions Starch/Starke, 42: 89-95.

Deffenbaugh, L.B., Walker C.E. 1989. Use of the rapid visco-analyser to measure starch pasting properties. Starch/Starke, 41: 461-467.
Delcour, J.A., Vansteelandt, J., Hytheir, M., Abecassis, J. 2000. Fractionation and reconstitution experiments provide insight into the role of starch gelatinization and pasting properties in pasta quality. Journal of Agricultural and Food Chemistry, 48: 3774-3778.

Dourado, F., Bastos, M., Mota, M., Gama, F.M. 2002. Studies on the properties of celluclast/eudragist L-100. Journal of Biotechnology, 99: 121-131.

Fontana, J.D., Mitchell, D.A., Molina, O.E., Gaitan, A., Bonfim, T.M.B., Adelmann, J., Grzybowski, A., Passos, M. 2008. Starch depolymerisation with diluted phosphoric acid and application of the hydrolysate in astaxanthin fermentation. Food Technology and Biotechnology, 46: 305-310.

Glenn, G.M., Irving, D.W. 1995. Starch-based microcellular foams. Cereal Chemistry, 72: 155-161.

Hattori, M., Yang, W., Takahashi, K. 1995. Functional changes of carboxymethyl potato starch by conjugation with whey protein. Journal of Agricultural and Food Chemistry, 43: 2007-2011.

Ihekoronye, A.I., Ngoddy, P.O. 1985. Integrated Food Science and Technology, Macmillan Eduction London, UK.

Jackowski, R., Czuchajowska, Z., Baik, B.K. 2002. Granular cold water gelling starch prepared from chickpea starch using liquid ammonia and ethanol. Cereal Chemistry, 79: 125-128.

Jane, J.L., Kasemsuwan, T., Leas, S., Zobel, H., Robyt, F.T. 1994. Anthology of starch granule morphology by scanning electron microscopy. Starch/Starke, 4: 121-129.

Jing-ming, L., Sen-lin, Z. 1990. Scanning electron microscope study on gelatinisation of starch granules in excess water. Starch/Starke, 42: 96-98.

Kunlan, L., Lixin, X., Jun, L., Junp, P., Guoying, C., Zuwei, X. 2001. Salt-assisted acid hydrolysis of starch to D-glucose under microwave irradiation. Carbohydrate Research, 331: 9-12.

Kuuti, L., Putkisto, K., Hyvarinen, S., Peltonen, S., Koivunen, K., Paulapuro, H., Tupala, J., Leskela, M., Virtanen, T., Maunu, S.L. 2010. Starch-hybrid fillers for paper. Nordic Pulp and Paper Research Journal, 25: 114-123.

Kweon, D.K., Choi, J.K., Kim, E.K., Lim, S.T. 2001. 
Adsorption of divalent metal ions by succinylated and oxidized corn starches. Carbohydrate Polymers, 46: 171-177.

Kweon, M.R., Sosulski, F.W., Han, H.S. 1997. Effect of aqueous ethanol cationization on functional properties of normal and waxy starches. Starch/Starke, 49: 202-207.

Lawal, O.S. 2004. Composition, physicochemical properties and retrogradation characteristics of native, oxidized, acetylated and acid-thinned new cocoyam (Xanthosoma sagittifolium) starch. Food Chemistry, 87: 205-218.

Liu, M., Cheng, R., Wu, J. 1996. Preparation and swelling properties of super-absorbent polymer. Chinese Journal of Polymer Science, 14: 48-56.

Majzoobi, M., Radi, M., Farahnaky, A., Jamalian, J., Tongdang, T. 2009. Physico-chemical properties of phosphoryl chloride cross-linked wheat starch. Iranian Polymer Journal, 18: 491-499.

Masuda, T., Kawano, K., Miyawaki, I. 1995. Process for production of starch sugars. United States Patent, patent No. 5391299/Date Feb. 21, 1995.

Meadow, F. 2002. Pasting process in rice flour using rapid visco analyser curves and first derivatives. Cereal Chemistry, 79: 559-562.

Milichrovsky, M. 2010. Water-A key substance to comprehension of stimuli- responsive hydrated recticular systems. Journal of Biomaterials and Nanobiotechnology, 1: 17-30.

Parovuori, P., Hamurien, A., Forssell, P., Autio, K., Poutanen, K. 1995. Oxidation of potato starch by hydrogen peroxide. Starch/Starke, 47: 19-23.

Qing, Q., Wu, Y., Tian, M., Liang, G., Zhang, L., Jun, M. 2006. Modification of starch for high performance elastomer. Polymer, 47: 3896-3903.

Radley, J.A. 1976. Examination and Analysis of Starch and Starch Products, pp. 220, Applied Science Publishers Ltd., London, UK.

Roman-Leshkor, Y., Moliner, M., Labinger, J.A., Davis, M.E. 2010. Mechanism of glucose isomerisation using a solid lewis acid catalysts in water. Angewandte Chimie International Edition, 49: 8954-8957.

Rutenberg, M.W. 1980. Starch and its modification. In: Handbook of Water Soluble Gums and Resins, R.L. Davidson (ed.), Chap 22, McGraw-Hill, New York,
USA.

Seechamananturakit, V., Suedee, R. 2012. The synthesis and characterisation of retinol-molecularly imprinted polymers as a selective sorbent in solidphase extraction. International Journal of Applied Science and Technology, 2: 81-93.

Sharma, B.R., Dhuldhoya, N.C., Merchant, V.C. 2006. Flocculants-an eco-friendly approach. Journal of Polymers and the Environment, 14: 195-202.

Song, S-S., Qi, H-B., Wu, Y-P. 2010. Preparation and properties of water absorbent composites of chloroprene rubber, starch and sodium acrylate. Polymers for Advanced Technologies, 33: 1778-1785.

Shogren, R.L., Biswas, A. 2006. Preparation of watersoluble and water-swellable starch acetates using microwave heating. Carbohydrate Polymers, 64: 16-21.

Stevenson, D.G., Biswas, A., Jane, J., Inglett, G.E. 2007. Changes in structure and properties of starch of four botanical sources dispersed in the ionic liquid 1-buty1-3-methyllilidazolium chloride. Carbohydrate Polymers, 67: 21-31.

Tam, L.M., Corke, H., Tan, W.T., Li, J., Collado, L.S. 2004. Production of bihon-type noodles from maize starch differing in amylose content. Cereal Chemistry, 81: 475-480.

Teramoto, N., Motoyama, T., Yosomiya, R., Shibata, M. 2003. Synthesis thermal properties and biodegradability of propyl-etherized starch. European Polymer Journal, 39: 255-261.

Verendel, J., Church, T.L., Andersson, P.G.. 2011. Catalytic one-pot production of small organics from polysaccharide. Synthesis, 11: 1649-1677.

Wang, L., Shogren, R.L., Willett, J.L. 1997. Preparation of starch succinates by reactive extrusion. Starch/Starke, 49: 116-120.

Whistler, R.L., BeMiller, J.N., Paschall, E.F. 1984. Starch: Chemistry and Technology, pp. 543-574, $2^{\text {nd }}$ edition, Academic Press, Miami, Florida, USA.

Willett, J.L. 1995. Complexes of oppositely charged ionic starches. Starch/Starke, 47: 29-32.

Wurzburg, O.B. 1986. Forty years of industrial starch research. Cereal Food World, 31: 897-903.

Xiao, C.M., Tan, J., Xue, G.N. 2010. Synthesis and properties of starch-g-poly (maleic anhydride-co- 
vinyl acetate). Express Polymer Letters, 4: 9-16. Xu, J., Zhou, J., Hanna, A.M. 2006. Melt-Intercalated starch acetate nanocomposite foams as affected by type of organoclay. Cereal Chemistry, 82: 105-110.

Xu, S., Feng, S., Peng, G., Yushan, A., Wanh, J. 2005. Removal of $\mathrm{Pb}(\mathrm{II})$ by cross-linked amphoteric starch containing the carboxymethyl group. Carbohydrate Polymers, 60: 301-305.
Yaacob, B., Mohd Amin, C.I., Hashim, K., Abu Bakar, B. 2011. Optimization of reaction conditions for carboxymethylated Sago starch. Iranian Polymer Journal, 20: 195-204.

Zhang, M., Zhang, S., Ju, B., Yang, J. 2007. A review of amphoteric starches in preparation and application. The Proceedings of The $3^{\text {rd }}$ International Conference on Functional Molecules, pp. 31-35. 